\title{
Role of Ilaj bid Dawa with Rationalising of Usoole Ilaj in the Treatment of Falij - A Pharmacological Perspective
}

\author{
Mohd Monis ${ }^{1}$, G. Sofi², Zarreen Baig ${ }^{3}$, Parwej Ahmad ${ }^{1 *}$
}

${ }^{1}$ Department of Ilmul Advia, Jamia Tibbiya Deoband, UP-247554, India

${ }^{2}$ Department of Ilmul Advia NIUM Bangalore, Karnataka-560091, India

${ }^{3}$ Department of Hifzane Sehat, AKTC, AMU Aligarh, UP-202002, India

*Corresponding author: Parwej Ahmad, Department of Ilmul Advia, Jamia Tibbiya Deoband, UP247554, India, E-mail: dr.parwej.ahmad@gmail.com

Received: July 03, 2017; Revised: October 02, 2017; Published: October 12, 2017

Copyright: (C2017 Monis M, et al. This is an open-access article distributed under the terms of the Creative Commons Attribution License, which permits unrestricted use, distribution, and reproduction in any medium, provided the original author and source are credited. The article has been previewed and authenticated by the Authors before sending the publication for print. The Journal, Editor and the Editorial Board are not entitled or liable to either justify or responsible for inaccurate and misleading data if any. It is the sole responsibility of the Author concerned.

Citation: Monis M, Sofi G, Baig Z, et al. Role of Ilaj bid Dawa with Rationalising of Usoole Ilaj in the Treatment of Falij - A Pharmacological Perspective. Int J Pharm Pharmacol 2017; 1: 119. doi: $\underline{10.31531 / 2581-3080.1000119}$

\begin{abstract}
Falij has been a major topic in Unani literature since centuries. The aspects of diagnosis and treatment based on Usoole Ilaj have remained a hallmark in the management of Falij. The packaged treatment of Falij includes almost all modalities of treatment- Ilaj Bil Ghiza, Ilaj Bid Dawa, and even surgical intervention. Unani medicine has dealt the disease management in stepwise, rational manner. The treatment strategies vary from the day patient seeks treatment and duration of the disease in the patient. Emphasizing on administration of Maul-Asal / usool in the initial days, munzij mushil therapy in the mid-course along with drugs for tabreed and taqwiyat administration in the later days is regarded as the standard treatment guideline for Falij. Along with this guideline rules related to Ayaame buhran which depend on the Mizaj of the person and the deranged khilt are taken into consideration for individualisation of the treatment is very evident. Since the treatment of any disease needs to be dealt keeping various features in view, so framing of usoole Ilaj has got paramount importance. The paper details the pharmacological basis of the treatment along with Usoole Ilaj of various phases of treatment delineating the Unani mechanism of action underlying each Afa'al (pharmacological actions) of Unani drugs.

Keywords: Falij, Unani drugs, Usoole Ilaj.
\end{abstract}

\section{Introduction}

The term Falij is derived from Arabic word "Falaja" means divide into two symmetrical parts [1]. Generally, word Falij is used for Istirkha. In particular, Falij means Istirkha or paralysis of half body from head to toe Monis M, et al. Int J Pharm Pharmacol longitudinally. It has two types; one involves head and other spares it [1,2]. Loss of movement, if developed in whole body is called Istirkha and if only one part is involved, is known as Falij (Table 1). Ancient physicians 
of Unani medicine were considering Falij as a disease in which one side of body is paralysed from head to foot. But according to Sahibe Kamil Falij is known as a disease in which one side of body excluding head is paralysed [3].

Falij is sometimes referred as loss of both motor and sensory functions. The differentiation between these two functions is described by Ibne Rushed: "Often if any one of these functions (hissand harkat) is lost other is also lost, though it is not mandatory" as mentioned by Galen also [4].

\section{Causes of Falij [3]}

- Nazfe Dimaghi (Brain haemorrhage)

- Obstruction of arteries of brain or clotting of blood.

- Brain tumour

- Epilepsy

- Talayyune Dimagh (Softness of Brain)

- Chorea

- Hysteria

Table 1: Types of Falij

\begin{tabular}{|l|l|l|l|l|}
\hline \multicolumn{1}{|c|}{$\begin{array}{c}\text { Falije Nisfi / } \\
\text { Falij }\end{array}$} & \multicolumn{1}{|c|}{$\begin{array}{c}\text { Falije Ma A } \\
\text { Laqwa } \\
\text { (Hemiplegia with } \\
\text { Facial Paralysis) }\end{array}$} & $\begin{array}{c}\text { Falije Aam } \\
\text { /Abu Bilqisya } \\
\text { (Quadriplegia) }\end{array}$ & $\begin{array}{c}\text { Falije Atrafi / } \\
\text { Falije Asfal } \\
\text { (Paraplegia) }\end{array}$ & Falije Maqami \\
\hline $\begin{array}{l}\text { When paralysis in } \\
\text { longitudinally in } \\
\text { half of the body }\end{array}$ & $\begin{array}{l}\text { When paralysis } \\
\text { occurs whole } \\
\text { longitudinal half of } \\
\text { the body including } \\
\text { head and face. }\end{array}$ & $\begin{array}{l}\text { When paralysis } \\
\text { occur in whole } \\
\text { body except face. }\end{array}$ & $\begin{array}{l}\text { When paralysis } \\
\text { occur in lower } \\
\text { part (lower limb) } \\
\text { of the body. }\end{array}$ & $\begin{array}{l}\text { Paralysis of } \\
\text { particular / } \\
\text { individual } \\
\text { organ. e.g. } \\
\text { Hand, foot, } \\
\text { tongue. }\end{array}$ \\
\hline
\end{tabular}

\section{Pathological Basis of Falij}

According to Galen:

(1) If posterior part of brain is injured Falije Nisfi (Hemiplegia) occur, if whole brain is injured saktah (Quadriplegia) occur.

(2) If first part of mabda-un-nukha (spinal cord) is affected whole body is paralyzed, if one side of spinal cord is affected same side of body is paralyzed.

(3) If both side of brain near spinal cord is affected Saktah (Quadriplegia) occur, if one side of Brain is affected Falije Nisfi occur [3].

Common cause of amraze Asaab mizaji or temperamental neurological disease is buroodat; either buroodat alone or associated with Balgham. Sauda is next to Balgham and Safra hardly causes neurological disease due to its fast dissolving nature [2].

The dominance of buroodat and rutoobat in any organ often interrupts the sensory and motor functions. Buroodat is opposite to Mizaj of Rooh. Therefore, it produces Takhdeer or decline of sense in Rooh. Rutoobat makes that organ blunt and insensitive [1]. Besides dominance of Buroodat and rutoobat, pathology in brain is also considered as a cause of movement disorders. According to Ibne Sina "loss or diminution of movement anywhere in the body is often because of lesion in the brain" [1]. According to Nafeesi "if the jarme urooq (vessel wall) is sulb or hard and blood is in excess quantity, rupture may occur in brain or heart vessels causing haemorrhage. It does not happen in other organs of body" [5].

The cause of Falij may be Sudda(any obstruction) in the course of nerves due to contamination of Khilte Balghami Ghaleez in brain or neurons, compression or dislocation of spinal cord, injury to these structures and residual effects of acute diseases like Meningitis [6].

Initially Imtila occurs in the part of Butoone Dimagh or Ventricles of brain, then suddenly it is dissolved from there and these Barid Balghami wastes descends to either left or right side of the body, whichever side is weaker [7].

Usually occurs in elderly when their brains are occupied with Khilte Barid (cold humours) and suddenly they come in contact with either hot or cold temperature which melt this Khilt, carrying it up to the root of nerves. Mostly this 
condition develops in persons with Zaeef (weakened) nerves [6].

\section{Usoole- Ilaj of Falij}

Betterment of moakkhar Dimagh: In all the diseases of nerves betterment of Moakhar dimagh is aimed primarily [1].

Taadeel-e Mizaj: Normalisation of Mizaj if only Kaifiyat is altered.

Tanqiyah: Elimination of causative matter if there is excess khilt. Sue-Mizaj Maddi is relieved by two courses; Istifraghe Mawad (elimination of causative matter) and Islahe Mizaj (correction of temperament). Sue-Mizaj Maddi is alleviated by drugs having Mulattif, Muqawi, Muarriq, Mulayyen, laxative and Muddirre baul properties. For Istifraghe Mawad two methods are used: first is Fasad or Venesection while second includes using Mushil or purgative drugs, Muqi or emetic drugs and Huqnah mushilah [2].

It is mandatory to use Mulattif drugs e.g. Anisoon, Tukhme Shibat, Ajwain, Tukhme Karafs, Beekh Badyan, Beekh Karafs, Beekh Izkhar, Aslussoos etc. In joshanda (Decoction) with Gulqand daily morning and after $4^{\text {th }}$, 7 th or $14^{\text {th }}$ day Mushil is given [8].

Mushil regime: while using mushilat (purgatives) following things should be taken into account.

- Addition of Muqawi Qalb (heart tonic): to potentiate and stabilize Roohe Haiwani.

- Muddirrat (Diuretics) not to be used in major quantity as it hinders the effect of mushily [9].

- Causative material is khilte balghami so munzije balgham drugs having talteef, Taqtee and Tehleel properties to be used. Drugs like turbud and ustookhoodus are added for effective elimination [1].

Taqwiyat: following Tanqiyah potentiation is provided to nerves and body massage [7] with HaarMizaj oils having Muhallil and Muqawie $A$ 'asaab actions, to dissolve the causative matter and potentiate the nerves [8].

\section{Drugs used according to usoole ilaj}

- For Tadeele Mizaj: Renowned Unani Physician Zakariya Razi (Rhazes 850-923 AD) advocated a prescription based on the principles of treatment (Usoole Ilaj).

"The treatment has to be started with Habbe Muntin for Tanqiyah (containing Ayarij Feqra 3.5 g, Shahme Hanzal, qunturiyoon Daqeeq, Usaara Qissul Hima, 1.75 g each, Farfiyun, Jund bedastar, Filfil, Hilteet,Sakbeenaj, jaosheer, Sheetraj Hindi, Khardal 0.35 g each with Aabe Suddab and any of Samaghiyat) for one day following massage with Roghane Qust, and orally Maul Asal and $7 \mathrm{gm}$ of Balazri (containing Zanjabeel, Aaqar Qarha, Shoneez, Qust, Filfil, Dare filfil, Waj 10 parts each, Barghe Suddab khushk, Hilteet, Juntiyana, Zarawand, Habbul ghaar, Junde bedastar, Sheetraj, Khardal and Baladur 5 parts each fried with Roghane Akhrout, with Asale khalis and Samaghiyat) for three days to be used for Tadeele Mizaj and this treatment cycle is to be given 10 times" [10].

- For Talteefe Mawad: In first seven days Gulqand + Maul buzoor or Gulqand + Maul usool is preferred.

Maul Buzoor: Aneesoon, Soya, Ajawain desi, Tukhme Karafs.

Maul Usool: Beekhe Badayan, Beekhe Karafs, Beekhe Izkar, Beekh Aslusoos.

- For Tanqiyah Mawad: No mushil should be given in initial stage of treatment, as Allama Nafeesi said "Mawad of falij is raw, not suitable for effect of mushil drugs and not able to excrete. If Mushil drug is given these raw matters become active and may be dangerous". So, after Talteefe Mawad and $N u z$, , elimination of causative matter is done with Mushil (Purgatives) drugs like Soya, Murznajosh, Nakhoona, Methi, Tukhme Arand, Injeer, Aslusoos, Shahad, Kanji, Roghane zaitoon, Tukhme hanzal and some Qurs like habbe sheetraj, habbe muqil etc. are used.

- For Taqwiyat-e-Asaab: After Tanqiyahe Mawad potentiation of nerve should be focused with application (Massage) of Haar Mizaj oils on vertebra and diseased part like Roghnae Arand, Roghane Zaitoon, Roghane 
Klakalnj, Roghane Sumbul Romi, Roghane Qust, Roghan Soya etc [3].

\section{Mamool-e-matab nuskha}

In initial phase of treatment for first seven days nothing is given in the form of diet except Maul Asal. Saqeel, indigestible, flatulent and food, drinks and drugs of cold temperament should be avoided.

\section{Preparation of Maul-Asal}

- $20 \mathrm{ml}$ Asale khalis boiled with water or Arqe Gao zaban $20 \mathrm{ml}$.

- Ustukhuddoos, Badranjeboya boiled in water then Asale khalis $(20 \mathrm{ml})$ is mixed.

After seven days Nuskha Munzij is given for 12 days.

Nuskha Munzij: Badyan, Beekh Badyan, Beekh Izkhar, Beekh Kibar 7 g each, Parsiyaooshan, Aslussoos muqasshar, Goazaban, Ustukuddoos $5 \mathrm{~g}$ each, Injeer zard
(3 adad), Maweez munaqqa (9 dana) soaked overnight in warm water, filtered in the morning and mixed with Khamira banafsha 40 ml. After 12 days-Mushil (purgatives) drugs are added with Munzijat.

Mushilat (purgatives): Sana makki, turbud safed $7 \mathrm{~g}$ each, Maghze amaltas, shire khisht 40 $\mathrm{ml}$ each, Turanjabeen, shakar surukh $40 \mathrm{ml}$ each, Sheerah maghz badam shsirin-5 in number each with Gulqand $40 \mathrm{~g}$.

After 12 days when Tanqiyah is completed, Taqwiyate Asaab (potentiation of nerves) is focused with administration of Khustae gaudanti $2 \mathrm{mg}$, Majoon Seer or Majoon Azaraqi or Majoon Jograj gogul $5 \mathrm{~g}$ with Arqe Gaozaban $120 \mathrm{ml}$ in the morning and Khamira Abresham Hakeem Arshad wala, Dawaul Misk Haar Jawahar wali with Arqe Gao zaban 20 $\mathrm{ml}$ in the evening.

Local Application: For better result after Tanqiyah, massage with Roghane Qust or Roghane Surkh on paralysed organ is done [3].

Table 2: Pharmacological basis of drugs used in the treatment of Falij

\begin{tabular}{|c|c|c|}
\hline Name of Drugs & Mizaj & Afa'al (Actions) \\
\hline $\begin{array}{l}\text { Aslussoos } \\
(\text { Glycyrrhiza } \\
\text { glabra) }\end{array}$ & $\operatorname{Hot}^{2} \operatorname{Dry}^{1}[11]$ & $\begin{array}{l}\text { Mulattif, Jali [12], Muqawie Asaab, excretes Rutoobat through } \\
\text { motion, normalizes Akhlat, cleanse the vessels of body, Mudirre } \\
\text { Baul Mudirre Haiz [11]. }\end{array}$ \\
\hline $\begin{array}{l}\text { Badyan } \\
\text { (Foeniculum } \\
\text { vulgare })\end{array}$ & $\begin{array}{ll}\text { Hot }^{2} & \text { Dry }^{1} \\
{[11,13]} & \end{array}$ & $\begin{array}{l}\text { Mufatteh, Mulatiff, Muddirre Baul, eliminates Rutubate Raqeeq } \\
\text { and akhtlate ghaliz lazij or viscid humours from stomach } \\
{[11,13] \text {. }}\end{array}$ \\
\hline $\begin{array}{l}\text { Ustukhuddoos } \\
\text { (Lavendula } \\
\text { stoechos) }\end{array}$ & $\begin{array}{l}\text { Hot }^{1} \text { Dry }^{2} \\
{[12]}\end{array}$ & $\begin{array}{l}\text { Mulattif, Muqawie Asaab, Mufatteh sudad, induces nuzuj in } \\
\text { Balgham and sauda and removes through bowel [12]. }\end{array}$ \\
\hline $\begin{array}{l}\text { Beekhe Badyan } \\
\text { (Foeniculum } \\
\text { vulgare) }\end{array}$ & $\begin{array}{l}\text { Hot }^{2} \text { Dry }^{2} \\
{[11]}\end{array}$ & Along with Maul Asal produces nuzuj in Balgham [11]. \\
\hline $\begin{array}{l}\text { Anisoon } \\
\text { (Pimpinella } \\
\text { anisum) }\end{array}$ & $\begin{array}{l}\text { Hot }^{2} \text { Dry }^{3} \\
{[11]}\end{array}$ & $\begin{array}{l}\text { Mulattif, Jali, Mufatteh, Kasire Riyah, Muddirre Baul, effective } \\
\text { in Falij when used with gulqand asali [11,12]. }\end{array}$ \\
\hline $\begin{array}{l}\text { Tukhme Karafs } \\
\text { (Apium } \\
\text { graveolens) }\end{array}$ & $\begin{array}{l}\text { Hot }^{2} \text { Dry }^{2} \\
{[11]}\end{array}$ & $\begin{array}{l}\text { Muhallil, Muarriq, Muddirre Baul, useful in Barid Balghami } \\
\text { amraz, enhances the effect of mushil drugs }[12,13] \text {. }\end{array}$ \\
\hline $\begin{array}{l}\text { Ood saleeb } \\
\text { (Paenia emodi) }\end{array}$ & $\begin{array}{l}\operatorname{Hot}^{2} \text { Dry }^{2} \\
\text { [11] }\end{array}$ & $\begin{array}{l}\text { Muqawie Asaab, Mufarreh, Mufatteh sudad, Mulattif and } \\
\text { Mujaffif properties [11,13]. }\end{array}$ \\
\hline $\begin{array}{l}\text { Beekhe Izkhar } \\
\text { (Andropogan } \\
\text { jwarancusa) }\end{array}$ & $\begin{array}{l}\text { Hot }^{1} \text { Dry }^{2} \\
{[11]}\end{array}$ & $\begin{array}{l}\text { Mufatteh, Mulayyen, Mulatiff, eliminates ghaliz. Akhlat after } \\
\text { producing Nuzuj, removes waste from Brain }[12,13] \text {. }\end{array}$ \\
\hline Barge Gaozaban & Hot $^{1}$ Ratab $^{1}$ & Mufarreh, potentiates Arwah, hararate ghairizi \\
\hline
\end{tabular}




\begin{tabular}{|c|c|c|}
\hline $\begin{array}{l}\text { (Borage } \\
\text { officinalis) }\end{array}$ & [11] & $\begin{array}{l}\text { raeesa, Mulayyen, Mulattif sauda, excretes Akhlate Muhtariqah } \\
{[11,12] .}\end{array}$ \\
\hline Gulqand Asli & $\begin{array}{l}\text { Hot }^{1} \text { Dry }^{1} \\
{[11]}\end{array}$ & $\begin{array}{l}\text { Induces nuzuj, talteef, Muqawi dimagh meda wa jigar improves } \\
\text { digestion, effective in Falij, facial palsy [11]. }\end{array}$ \\
\hline $\begin{array}{l}\text { Barge Sana } \\
\text { (Cassia } \\
\text { angustifolia) }\end{array}$ & $\begin{array}{l}\text { Hot }^{1} \text { Dry }^{1} \\
{[13]}\end{array}$ & Mushil for murrah safra and Balgham [13]. \\
\hline $\begin{array}{l}\text { Turbud } \\
\text { (Ipomia } \\
\text { turputhum) }\end{array}$ & $\begin{array}{l}\text { Hot }^{3} \text { Dry }^{3} \\
{[13]}\end{array}$ & $\begin{array}{l}\text { Mushil, eliminates Balghami lazij from brain through purgation, } \\
\text { beneficial for Falij, convulsion and other neurological disorders } \\
{[12,13] \text {. }}\end{array}$ \\
\hline $\begin{array}{l}\text { MaghzeFloos } \\
\text { Khayar Shanber } \\
\text { (Cassia fistula) }\end{array}$ & $\begin{array}{l}\text { Hot }^{1} \quad \text { Wet }^{1} \\
{[11]}\end{array}$ & $\begin{array}{l}\text { Mushil, Mulayyen, purifies the Nerves, along with turbud it } \\
\text { purges Balgham [11-13]. }\end{array}$ \\
\hline $\begin{array}{l}\text { Roghan } \quad \text { zard } \\
\text { (ghee) }\end{array}$ & $\begin{array}{l}\mathrm{Hot}^{1} \mathrm{Wet}^{1} \\
{[13]}\end{array}$ & $\begin{array}{l}\text { Muhallil, Munzij, Mulayyen, musakkin, normalizes the } \\
\text { consistency of causative matter, helps to remove the blockage } \\
\text { and potentiates Brain }[11,13] \text {. }\end{array}$ \\
\hline $\begin{array}{l}\text { Roghane } \\
\text { Malkangni } \\
\text { (Celastrus } \\
\text { paniculatus) }\end{array}$ & $\begin{array}{l}\mathrm{Hot}^{1} \\
{[11]}\end{array}$ & $\begin{array}{l}\text { Muqawie Asaab, used in Falij, Laqwa, Wajaul mafasil, Niqras, } \\
\text { Khadar and zuafe Asaab [11]. }\end{array}$ \\
\hline
\end{tabular}

\section{Scientific studies related to some commonly used drugs (Table 2)}

Aslussoos: Roots and rhizomes of G. glabra have been studied; study suggested that the aqueous extract of roots 250 and $500 \mathrm{mg} / \mathrm{kg}$ possess a Cerebro protective effect in sod. Nitrite induced hypo toxic rat which may be mediated by its anti-oxidant effect [14].

Beekh Badyan: In vivo, both essential oil andAnethole (the main component of oil) orally administered in a sub-acute treatment to mice (30 $\mathrm{mg} \mathrm{kg}$ per day for 5 days) showed significant anti thrombotic activity preventing the paralysis induced by collagen-epinephrine i.v. injection (70-83\%) protection respectively [15].

Ustukuddoos: L stoechus flowers were studied for its possible Anti-convulsant, Antispasmodic activity.It increased the latency of convulsions induced by pentylene tetrazole. Lavender from Lavandula angustifolia also decreases the tone in the skeletal muscle preparation of phrenic nerve- diaphragm of Rats [16].

Aneesoon: Neuro protective effect of Anise oil was observed [17].

TukhmeKarafs: Apigenin was studied on the contraction of rat thoracic aorta, it was concluded that Apigenin relaxes rat thoracic aorta mainly by suppressing the Calcium influx through both voltage receptor-oriented calcium channel [18].

Ood Saleeb: sedative, anti-inflammatory activities were assessed, and it has blocking effect on neuromuscular junction [19].

Barge Goazaban: Leaves were tested for flavonoids, coumarins, sterols and tannin, produced a contraction- dependent relaxation of spontaneous and $\mathrm{k}+(80 \mathrm{mM})$ induced contraction in isolated rabbit jejunum preparation, suggestive of calcium antagonist effect [20].

Barge Sana: Cassia angustifolia contains anthraquinone, carbohydrates, flavonoids, glycosides. Senna is a potent laxative and its use in chronic constipation patient has been assessed [21].

Turbud: Anti-secretory, ulcer protective, antiinflammatory, hepatoprotective, anti-bacterial and anti-oxidant activity was confirmed [22].

Roghan Malkangni: Borrelli et al. proved that extract of Celastrus paniculatus seeds exerts a powerful myogenic and L-type calcium dependent relaxing effect in the isolated Rat and the human ileum is sensitive to the inhibitory effect of its extracts [23].

\section{Conclusion}


The present study revived the treatment guidelines of Falij in Unani medicine. It also attempted to rationalise the same by documenting various scientific reports of the drugs used in Falij. Further studies in clinical setting are required to validate the treatment guidelines.

\section{Conflict of Interest}

None declared.

\section{Funding}

None declared.

\section{References}

1. Sina I. Al Qanoon Fit Tib. New Delhi: Idara Kitbush Shifa 2010; 3: 582-584.

2. Baghdadi. Kitabul Mukhtarat Fit Tib. New Delhi: CCRUM 2004; 3: 53-55.

3. Kabeeruddin A. Tarjumah Kabeer Sharah Asbab. New Delhi: Idara Kitabush Shifa 2009; 1: 124-129.

4. Rushd I. Kitabul Kulliyat. New Delhi: CCRUM 1987; 1: 87.

5. Husain. Mualijate Nafeesi. Lucknow: Munshi Nawal Kishore 1906; 3: 106-107.

6. Majoosi. Kamilus Sanaah. New Delhi: Idara Kitbush Shifa 2010; 465-467.

7. Tabri. Al Mualejatul Buqratiyah. New Delhi: CCRUM 1994; 1:420.

8. Arzani A. Tibbe Akbar. New Delhi: Deoband: Faisal publications; 72-75.

9. Jurjani AH. Zakheera Khwarzam Shahi. New Delhi: Idara Kitabus Shifa 2010; 06: 76-80.

10. Razi. Kitabul Mansoori. New Delhi: CCRUM 1991; 320.

11. Rampuri NG. Khazainul Advia. New Delhi: Idara Kitabus Shifa: 220-1260.

12. Maghribi I. Kitabul Fatah Fittadawi Min Jameei Sunoofil Amraz Wash Shakawi. Delhi: AYUSH 2007; 1: 46-224.

13. Baitar I. Al Jameul Mufridat Advia wal Aghziya. $1^{\text {st }}$ ed. New Delhi: CCRUM 1985; 1: 29-345.
14. Murlidharan P, Balamurugan G, Venu B. Cerebroprotective effect of Glycyrrhiza glabra Linn. root extract. Bangladesh J Pharmacol 2009; 4: 60.

15. Tognolini M, Ballabeni V, Bertoni S, et al. Protective effect of $F$. vulgare essential oil andanethole in an experimental model of thrombosis. Pharmacol Res 2007; 56: 254260.

16. Balchin LM, Hart S. Studies of the mode of action of essential oil of Lavender. Phytother Res 1999; 13: 540-542.

17. Karimzadeh F, Hosseine M, Mangeng D, et al. Anticonvulsant and neuroprotective effect of Pimpinella anisum in rat brain. BMC Complement Altern Med 2010; 12: 19.

18. KO FN, Huang TF, Teng CM. Vasodilatory mechanism of action of apigenin isolated from Apium graveolens in rat thoracic aorta. Biochim Biophys Acta 1999; 115: 69-74

19. Riaz N, Malik A, Rehman A, et al. Lipoxygenase inhibiting and antioxidant oligostilbene and monoterpene galactoside from Paeonia emodi. Phytochemistry 2004; 65: 1129-1135.

20. Gilani AH, Bashir S, Khan A, et al. Pharmacological basis for the use of Borago officinalis in gastrointestinal, respiratory and cardiovascular disorders. J Ethnopharmacol 2007; 114: 393.

21. Picon PD, Picon RV, Costa AF, et al. Randomized clinical trial of phytotherapic compound containing Pimpinella anisum, Foeniculum vulgare, Sambucus nigra and Cassia angustifolia for chronic constipation. BMC Complement Altern Med 2010; 10: 17.

22. Kohli KR., Nipanikar SU, Kadbhane KP, et al. A comprehensive review on Trivrit (Ipomea turpethum). Int J Pharma Bio Sci 2010; 1: 443-452.

23. Borrelli F, Borbone N, Capasso R., et al. Potent relaxant effect of a Celastrus paniculatus extract in the rat and human ileum. J Ethanopharmacol 2009; 122: 234238. 
This manuscript was peer-reviewed

Mode of Review: Single-blinded

Editor: Dr. Imran Kazmi

International Journal of Pharmaceutics and Pharmacology is an open access, peer reviewed journal published by Edwiser International.

Submit your valuable manuscript at-

editor.ijpp@edwiserinternational.com

submit.manuscript@edwiserinternational.com

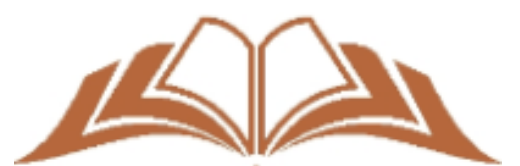

EDW $\mathrm{W}$ S E R
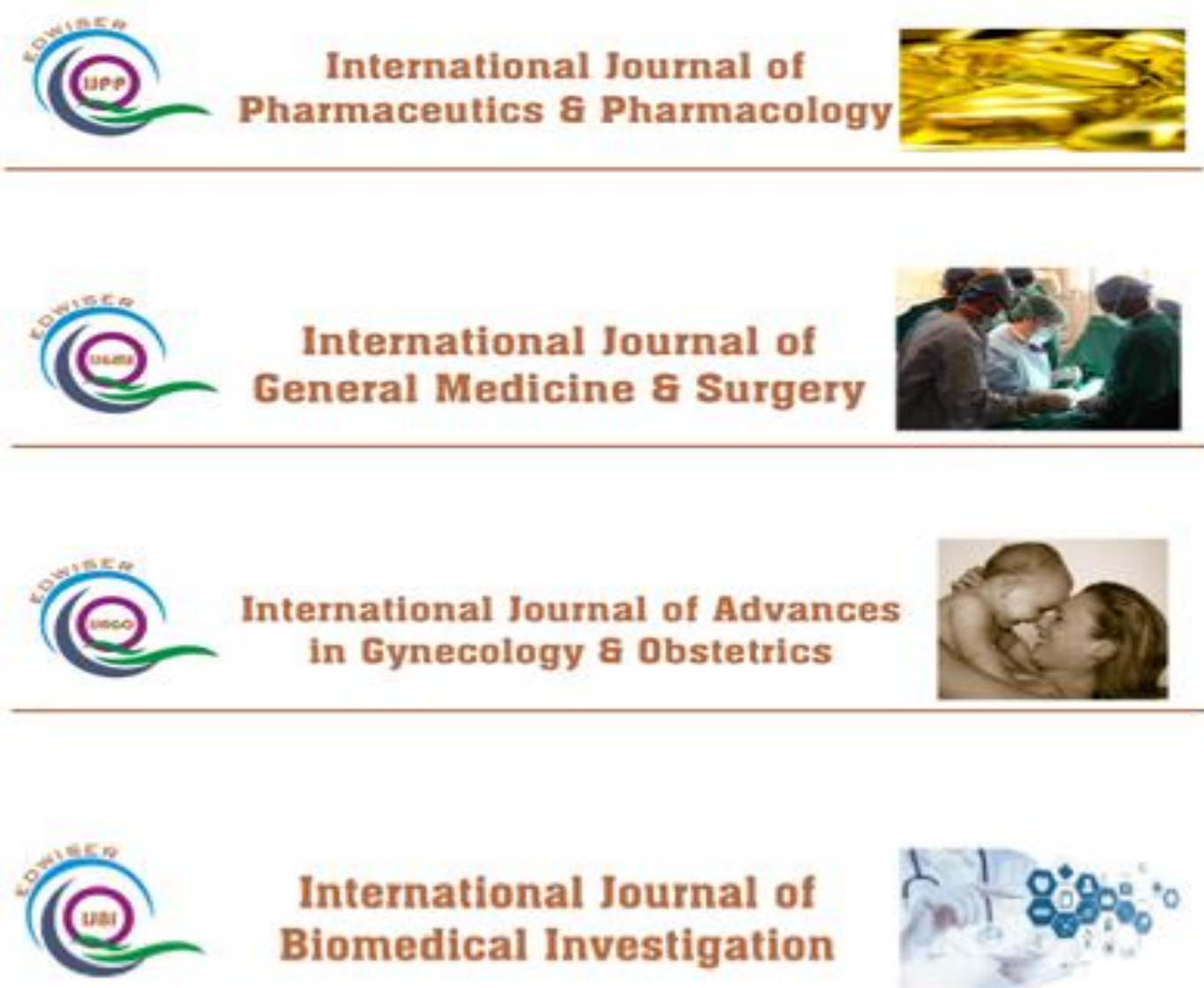

International Journal of Biomedical Investigation

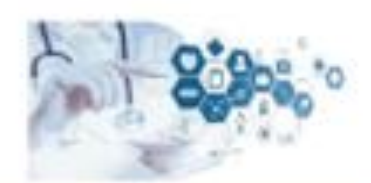

International Journal of Cardiopulmonary Diseases \& Rehabilitation

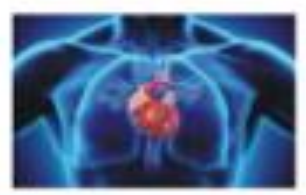

